\title{
Adam Segal, Digital Dragon. High-Technology Enterprises in China
}

Ithaca and London, Cornell University Press, 2003, 188 p., and Kellee S. Tsai, Back-Alley Banking, Private Entrepreneurs in China, Ithaca and London, Cornell University Press, 2002, 316 p.

\section{Gilles Guiheux}

\section{(2) OpenEdition}

12 Journals

Édition électronique

URL : http://journals.openedition.org/chinaperspectives/400

DOI : 10.4000/chinaperspectives.400

ISSN : 1996-4617

Éditeur

Centre d'étude français sur la Chine contemporaine

\section{Édition imprimée}

Date de publication : 1 août 2003

ISSN : 2070-3449

Référence électronique

Gilles Guiheux, " Adam Segal, Digital Dragon. High-Technology Enterprises in China », China Perspectives [En ligne], 48 | july-august 2003, mis en ligne le 24 novembre 2006, consulté le 21 septembre 2020. URL : http://journals.openedition.org/chinaperspectives/400 ; DOI : https://doi.org/ 10.4000/chinaperspectives.400

Ce document a été généré automatiquement le 21 septembre 2020.

(C) All rights reserved 


\section{Adam Segal, Digital Dragon. High- Technology Enterprises in China}

Ithaca and London, Cornell University Press, 2003, 188 p., and Kellee S. Tsai, Back-Alley Banking, Private Entrepreneurs in China, Ithaca and London, Cornell University Press, 2002, 316 p.

\section{Gilles Guiheux}

\section{NOTE DE L'ÉDITEUR}

Translated from the French original by Nick Oates

1 IN MANY respects, the dynamism of China's economic growth represents a huge challenge for the social sciences. Unlike Western capitalism, the economy and in particular the private sector over the last ten years have developed in the absence of a coherent corpus of laws regulating the systems and transfers of property ownership. In another paradox, some analysts have held the view that China has followed a development model inspired by the experiences of its Japanese, Korean and Taiwanese neighbours, but the hypothesis of a "developmentalist" central Chinese state is contradicted by the variety of local situations and the distance that separates them from the directives formulated at the central level. The works of Adam Segal and Kellee S. Tsai both offer important responses to the challenge presented by the chinese case to classical analyses of economic development.

2 The object of Adam Segal's study is the high-technology enterprises under private management (the minban or minying kejiqiye). These enterprises, neither public nor private, in fact come under various systems of property ownership: they are sometimes state enterprises, sometimes collective enterprises, sometimes private enterprises ${ }^{1}$. The goal of the author is not only to show that the policies implemented to promote the development of these enterprises have differed from one place to another in China, but also to explain why. To do this, he examines four big cities: Peking, Shanghai, Xi'an and Guangzhou. He has hunted through the local press, read the administrative reports 
or the development plans for this sector of activity, and conducted over a hundred meetings with entrepreneurs as well as representatives of the administrative departments concerned.

3 To understand the variety of strategic choices operated by the authorities, Segal places them in the framework of local economic systems that he characterises by four elements: the technological and scientific resources available, the balance of power between the different administrative departments, the relations between the local government and the central authorities, and local traditions in the field of economic policy. These four elements define an institutional configuration specific to the area under consideration, which, he concludes, has fashioned the local path that has been taken when it comes to the promotion of the high-tech enterprises. The heart of the work is thus formed by the chapters in which the author reconstitutes these local trajectories. Each time, the author directs his questions at three aspects: the legal form (the system of property) adopted by the enterprises, the type of financing that has been implemented, and the relationship between the local government and the enterprises. Studying the emergence of the same sector of activity at several points on Chinese soil, the author logically associates the characteristics of the local system with the success or failure of the promotion of the high-tech industries.

Some of the results of the survey may well come as a surprise. For example, contrary to the received idea that the government is omnipresent in Peking, Segal reveals that the high-tech enterprises have developed in a way that has been largely independent of the central authorities. It is only in a second phase, after their initial success, that the local government and the State Council have set up a zone at Zhongguancun where these enterprises are given a privileged welcome. This trajectory is very obviously to be placed in the context of the characteristics of the local economic system. Peking benefits from the largest concentration of universities and other public research institutes, yet at the same time the tools of industrial planning are less developed here than in other cities such as Shanghai. In that city, the development of the high-tech industries has been concentrated around the large state enterprises. The situation is comparable in Xi'an, where the local economy is dominated by state enterprises and the defence industries. For its part, Guangzhou has logically appealed to foreign capital, in particular to entrepreneurs from Hong Kong.

5 In her work, Kellee S. Tsai examines the contribution made by informal financing to China's growth ( $70 \%$ of the enterprises at which she conducted surveys have resorted to one form or another of informal financing: collateral loans, tontine schemes, loans from family or friends, etc.). The three questions at the core of the work are: how can the wide dissemination of informal modes of financing be explained while they are actually illegal? Why does the informal financing on offer vary from one place to another in China? Why, in the same local area, do private entrepreneurs have different ways of accessing this financing? Tsai looks not only at the diversity of the local situations, but also at the varying usage that private entrepreneurs make of the same financing resources available within a given territory.

6 The argument is supported by a work that covers a considerable amount of terrain and involves more than twenty months of research conducted between 1994 and 2001 (which gives Tsai the authority to comment on developments $\left({ }^{2}\right)$, three hundred interviews with private entrepreneurs, executive officers of banks and administrative departments, in eighteen different locations in the provinces of Fujian, Zhejiang and 
Henan. The scope of the sampling allows certain hypotheses to be verified statistically (correlation tests). Thus, in sixteen of the eighteen localities investigated, the attitude of the local government towards the private sector (repressive or favourable) explains the degree of institutional diversity when it comes to informal financing.

7 The data also reveals that the strategy of individual entrepreneurs where financing is concerned depends on the length of their experience, the scope of their political relations, their residential origins as well as their sex. Tsai thus also stresses the diversity of the private entrepreneurs themselves. If, under given conditions, they make different use of the modes of financing available, it is because each one is characterised by a different political and social identity. Thus, an entrepreneur who enjoys solid political relations will be more disposed to mobilise the formal credit system than a migrant woman possessing few points of contact in the local society.

The response that Tsai gives to the hypothesis of a "developmentalist" Chinese state, even local, consists in what she calls the "the local logics of economic possibility". The author emphasises both the importance of the heritage of the Maoist period (the presence of state enterprises or powerful collective institutions) and the initiative of the entrepreneurs who, though certainly embedded in the given local structures, nevertheless possess capacities for innovation in the use of the available resources. What matters for the understanding of the processes underway are thus less the impulses given by the central government than the local configurations that are in place.

9 Naturally enough, the two works share the same comparative method, which stresses the break-up of chinese territory into several parts. This choice allows two dangers to be avoided, one being abstract and misleading generalisations on the scale of a country that contains so many contrasts, the other the impasses of a pure monograph. The chosen method is extremely fruitful here and allows both authors to construct a number of typologies: four modes of development for the high-tech enterprises for Adam Segal (p. 18); and three development models in the informal financial sector for Kellee Tsai (p. 256).

10 The authors also insist on the necessity of deconstructing the central state as well as the local governments. The chinese state is not to be considered as a coherent machine that marches to the beat of the same drum. One would search in vain for a central Chinese administration that would be the equivalent of Japan's MITI or Singapore's EPD. In China, it is necessary to envisage the state as a decentralised structure, yet "embedded" in specific institutional, political and social configurations. Adam Segal is interested precisely in the interactions between the local and central echelons. Kellee Tsai clearly demonstrates that at the level of the same city the Bank of China and the Bureau of Industry and Commerce can have divergent interests (while the former wishes to suppress the informal types of credit, the latter may actively support them, as collateral loan agencies or credit co-operatives are sources of revenue). At each level - national, provincial, municipal, district or village - the party-state is composed of administrative and political organs that work in co-operation with but are simultaneously rivals to each other.

11 Another conclusion common to the two works is the weight exerted by the past. Adam Segal evokes the "traditional patterns of industrial policy" which vary from one area to another and help to explain the capacity of local governments to formulate and implement an industrial policy. Kellee Tsai stresses the Maoist heritage, a factor that 
structures local logics. Where the state did not organise economic development during the Maoist period, the private economy is active (as in Wenzhou) and the local authorities are agreeable to the creation of new forms of financing ${ }^{3}$.

Certainly, the reading of the two works leaves something to be desired. Adam Segal does not furnish, for example, any indices of the economic or technological performance of the enterprises under consideration. To what extent are these Chinese high-tech companies genuinely innovative? Do a number of them not merely content themselves with assembling parts, extensively imported, and are they thus not simple manufacturing enterprises? Has China not planted its territory with technology parks (gaokexue yuan) that, when they are not deserted, primarily welcome enterprises on the look-out for tax exemptions and easy access to credit? Is the comparison between Zhongguancun and Silicon Valley in California relevant (the thought here is in particular directed at the question of the circulation of information between enterprises with links to universities or contributing research centres)? Kellee Tsai, for her part, sometimes tries her reader's patience with the immensity of the literature of sociology, economics, anthropology and political science that she draws on (is the reference to the habitus of Pierre Bourdieu, p. 259, really necessary?). Despite these comments, the two authors offer a considerable wealth of results and open up a path that is full of promise.

\section{NOTES}

1.On this point, see Bennis Wai-yip So, "Evolution of Minying High-tech Enterprises in China: Legitimizing Private Ownership", Issues\& Studies, vol. 37, No. 5, SeptemberOctober 2001, pp. 76-99, and our article "The Incomplete Crystallisation of the Private Sector", China Perspectives, No. 42, July-August 2002, pp. 24-35.

2.The creation in 1984 in Wenzhou of the first bank that was closed in 1989 for example (pp. $140 \mathrm{ff}$.).

3.That is not to say that in the areas where the local administration continues to entertain very close links with state or collective enterprises private entrepreneurs for whom access to formal credit is difficult do not display a great capacity for innovation in terms of financing. This is the case in the province of Henan, where although the private sector is relatively underdeveloped, there is a great variety in the types of informal financing. 